\title{
Improved Salt Tolerance of Lamtoro (Leucaena leucocephala) through the Application of Indigenous Mycorrhiza
}

\author{
Delvian Delvian $\left.{ }^{1}\right)^{1}$ and Adrian Hartanto $\left.{ }^{2}\right)^{2}$ \\ ${ }^{1}$ Department of Forestry, Faculty of Forestry, Universitas Sumatera Utara, Medan, North Sumatra 20155, Indonesia \\ ${ }^{2}$ Department of Biology, Faculty of Mathematics and Natural Sciences, Universitas Sumatera Utara, Medan, \\ North Sumatra 20155, Indonesia \\ Correspondence should be addressed to Delvian Delvian; delvian@usu.ac.id
}

Received 17 May 2021; Accepted 24 July 2021; Published 31 July 2021

Academic Editor: Monika Marković

Copyright (c) 2021 Delvian Delvian and Adrian Hartanto. This is an open access article distributed under the Creative Commons Attribution License, which permits unrestricted use, distribution, and reproduction in any medium, provided the original work is properly cited.

\begin{abstract}
Salt stress is one of the serious abiotic stressors which limit the growth and development of important crops in agricultural lands. Arbuscular mycorrhizal fungi (AMF) have been implemented as a strategy to mitigate the adverse effects due to an impact of salt stress through the structural and physiological adjustment. This study aimed to determine a relationship between salinity levels $(0$, 150,300 , and $450 \mathrm{mM} \mathrm{NaCl}$ ) and AMF treatments (Glomus manihotis, Glomus etunicatum, and G. manihotis + G. etunicatum) to the salt tolerance of Leucaena leucocephala seedlings in a greenhouse. Salinity reduced the plant height, biomass, and root colonization by AMF. However, the inoculation of AMF, especially the consortium, ameliorated the negative effects by stabilizing the growth performance and supporting the photosynthetic outputs through optimum nutrient and mineral absorptions. These results were indicative through a significant interaction between salinity levels and the types of AMF treatment in all parameters except in the total leaf protein and proline contents from the two-way ANOVA results. Root colonization was highly correlated with the plant height, biomass, and total carbohydrate content with a maximum contribution conferred by the AMF consortium, based on Pearson's correlation coefficient test and PCA analysis. Our study then showed the positive impact of AMF toward salt tolerance by L. leucocephala with potential application and cultivation in salt-stressed ecosystems.
\end{abstract}

\section{Introduction}

Conversion of agriculture land into human settlement and industry has led to the decrease territory of arable lands. Upcoming climate change with consequences on the rise of sea level, sea water intrusion, and high evaporation was regarded as a major environmental issue which also posed some challenges in the cultivation of economical crops [1]. The consequence of this land conversion has directed farmers to utilize marginal lands such as saline soils [2]. Saline soils are characterized by their high salt content $\left(\mathrm{NaCl}, \mathrm{Na}_{2} \mathrm{CO}_{3}, \mathrm{Na}_{2} \mathrm{SO}_{4}\right)$ with electric conductivity $>4 \mathrm{dS} /$ $\mathrm{m} \approx 40 \mathrm{mM} \mathrm{NaCl}$ which deter the optimum growth and development of many horticultural crops around the world [3]. Saline soils in Indonesia cover an area of 27,4 million ha with potential being utilized for cultivation of salt tolerant crops [4]. However, excessive salt ions will limit native plants to thrive in the environment by decreasing plant height, lowering photosynthetic capacity and nutrient absorption with death penalty [5]. Some strategies have been employed to maximize the use of saline soils, one of which through the application of soil-borne microorganisms, such as bioamelioration by arbuscular mycorrhizal fungi (AMF) $[6,7]$.

Lamtoro (Leucaena leucocephala (Lam.) de Wit) from family Fabaceae is a pioneer legume species from Central America known for its notable nitrogen fixation capacity and fast-growing woody plant. The species has been utilized as biofertilizer or green leaf manuring to improve soil fertility, as forage for animal feed, and a prominent source of high quality timber [8-10]. In Indonesia, the species has been cultivated since 1800 with some of its cultivars being recognized as important timber producers due to its valuable traits $[11,12]$. Therefore, the species is well-adapted towards abiotic stress in marginal lands while being proved useful for 
afforestation and landscaping [13]. Studies have also revealed the significant contribution of AMF to the improved growth performance of L. leucocephala seedlings under stress condition especially in heavy metal contaminated sites [14-16].

Plants maintain their growth and development under salinity stress through biological adjustment to thrive in the harsh environments. The adjustment may vary such as accumulation of compatible solutes, production of ROSscavenging enzymes, induction of phytohormones, and ionhomeostasis balancing [17]. However, the performance may be limited due to the rapidly changing environment and high influx of salt ions which demand a more stable adjustment from the plant [18]. Symbiotic establishment between AMF and plant species was initiated 400 million years ago and considered as stable mutualism which form inter-regulation and enhancement on the survivability of terrestrial plants [19]. The salt resistance and growth improvement conferred by AMF may be different across species and strain origins. Claroideoglomus etunicatum colonizing the roots of rice plant (Oryza sativa L.) showed enhancements in terms of photosynthetic productivity and stomatal conductance under salinity stress [20]. Another strain of C. etunicatum colonizing the roots of a halophytic $\mathrm{C}_{4}$ grass species Aeluropus littoralis has been reported to increase the shoot and root biomass of its host following other adaptive traits such as improved stomatal conductance, synthesis of compatible solutes, and balanced ion uptakes [21]. Another example from legume species alfalfa (Medicago sativa L.), the coinoculation of AMF and rhizobia improved the yield through increases in mycorrhizal colonization, rhizobia nodulation, root $\mathrm{Ca}$ content, and shoot proline content [22].

Based on our understanding, the information of AMF colonization in L. leucocephala under saline conditions is still limited. The present study then investigates the role of two indigenous AMF following their biological outputs in maintaining the normal growth of L. leucocephala under salinity stress by examining physiological adjustment by the plant. This study will also discriminate which fungal species is the better option as an AM fungal inoculant or AMF consortium for improving salt tolerance in L. leucocephala.

\section{Materials and Methods}

2.1. AMF Identification and Inoculum Preparation. Two indigenous AMF isolates, Glomus sp1 and Glomus sp2, were isolated in a previous study using Pueraria javanica as host through trap cultures and single spore isolation. Spore suspension was prepared for molecular identification. Genomic DNA extraction and nested polymerase chain reaction (PCR) were performed commercially by Macrogen, Inc. (Singapore). Molecular identification of AMF was based on the amplified nuclear rDNA fragments using a pair of SSUmAf/LSUmAr and SSUmCf/LSUmBr primers [23]. Crude inoculum was prepared in sterilized zeolite filled with colonized root segments of $P$. javanica maintained in dry state. The AMF inoculum was then preserved for further experiment.
2.2. Plant and Soil Treatments. Seeds of L. leucocephala, provided by the Research Institute of Haurbentes (Bogor, Indonesia), were disinfected with $1 \%(\mathrm{v} / \mathrm{v}) \mathrm{NaOCl}$ solution for $20 \mathrm{~min}$, washed three times with distilled water, and soaked in sterile water for $24 \mathrm{~h}$. After that, the seeds were put on a seed tray covered with river sand and rapidly germinated in a greenhouse. The seedlings were exposed to sunlight for $12 \mathrm{~h}$ every day, and the water was given conditionally. Once the seedlings had grown to $10 \mathrm{~cm}$ and produced two leaves, they were put into a plastic cup (93.4 $\mathrm{mm} \times 65.82 \mathrm{~mm}, 5$ holes) filled with sterilized zeolite ( particle size $=1 \mathrm{~mm})+\mathrm{AMF}$ inoculum in a ratio of $1: 1$ (w/w) or in a ratio of 2:1:1 for AMF consortium (Glomus sp $1+$ Glomus sp2) and maintained in a greenhouse for salinity treatment.

2.3. Experimental Design. The experiment was arranged in a Randomized Complete Block Design (RCBD) with two factors (Figure 1): AMF inoculation (Glomus sp1, Glomus sp2, and Glomus sp1 + Glomus sp2) and salt stress (0, 150, 300 , and $450 \mathrm{mM}$ ) and five replications for each, totaling $4 \times 4 \times 5=80$ pots. The 60 seedlings inside the plastic cups were transplanted in contact with the top layer of $15 \mathrm{~cm} \times 14 \mathrm{~cm}$ pots (no hole) filled with saline waters (150, 300 , and $450 \mathrm{mM}$ ) and grown in a greenhouse. Pots without AMF inoculum were prepared as nonmycorrhizal controls. The seedlings were watered with distilled water every day. Supplementation of Hyponex ${ }^{\circledR}(\mathrm{N}, \mathrm{P}, K=25 \%, 5 \%, 20 \%)$ was given once in two weeks with a concentration of $2 \mathrm{~g} / \mathrm{L}$. The treatments were maintained for 1 month.

2.4. AMF Colonization. After 1 month of saline treatment, the seedlings were harvested, and the fresh roots were collected. The roots were washed, cut into $1 \mathrm{~cm}$ segments, and fixed with $10 \% \mathrm{KOH}$ at $90^{\circ} \mathrm{C}$ until being colorless. The root segments were fixed with $10 \% \mathrm{HCl}$ and stained with $0.05 \%$ trypan blue at $90^{\circ} \mathrm{C}$ for $15 \mathrm{~min}$ [24]. The AM colonization rate was determined by the gridline intersection method [25]. Data were recorded as the proportion of root length colonized.

2.5. Plant Height and Total Biomass. Measurement of growth response under saline treatment was expressed as the average growth in plant height over one month, determined from the beginning and at the end of a 1-month saline treatment. The seedlings were dried in an oven at $60^{\circ} \mathrm{C}$ until constant weight (g) to obtain the total biomass of L. leucocephala.

2.6. Total Protein Content. Fresh leaves from each treatment were sampled and washed with running tap water. One $g$ of leaves was crushed and diluted with $20 \mathrm{~mL}$ of phosphate buffer saline ( $\mathrm{pH}$ 7.4). The solution was centrifuged at $10,000 \mathrm{rpm}$ for $10 \mathrm{~min}$ and then supernatants were collected. Five $\mathrm{mL}$ of Quick Start ${ }^{\mathrm{TM}}$ Bradford Protein Assay (Bio-Rad, US) containing Coomassie Brilliant Blue G-250 was mixed with $0.1 \mathrm{~mL}$ of sample solution [26]. Samples were incubated 


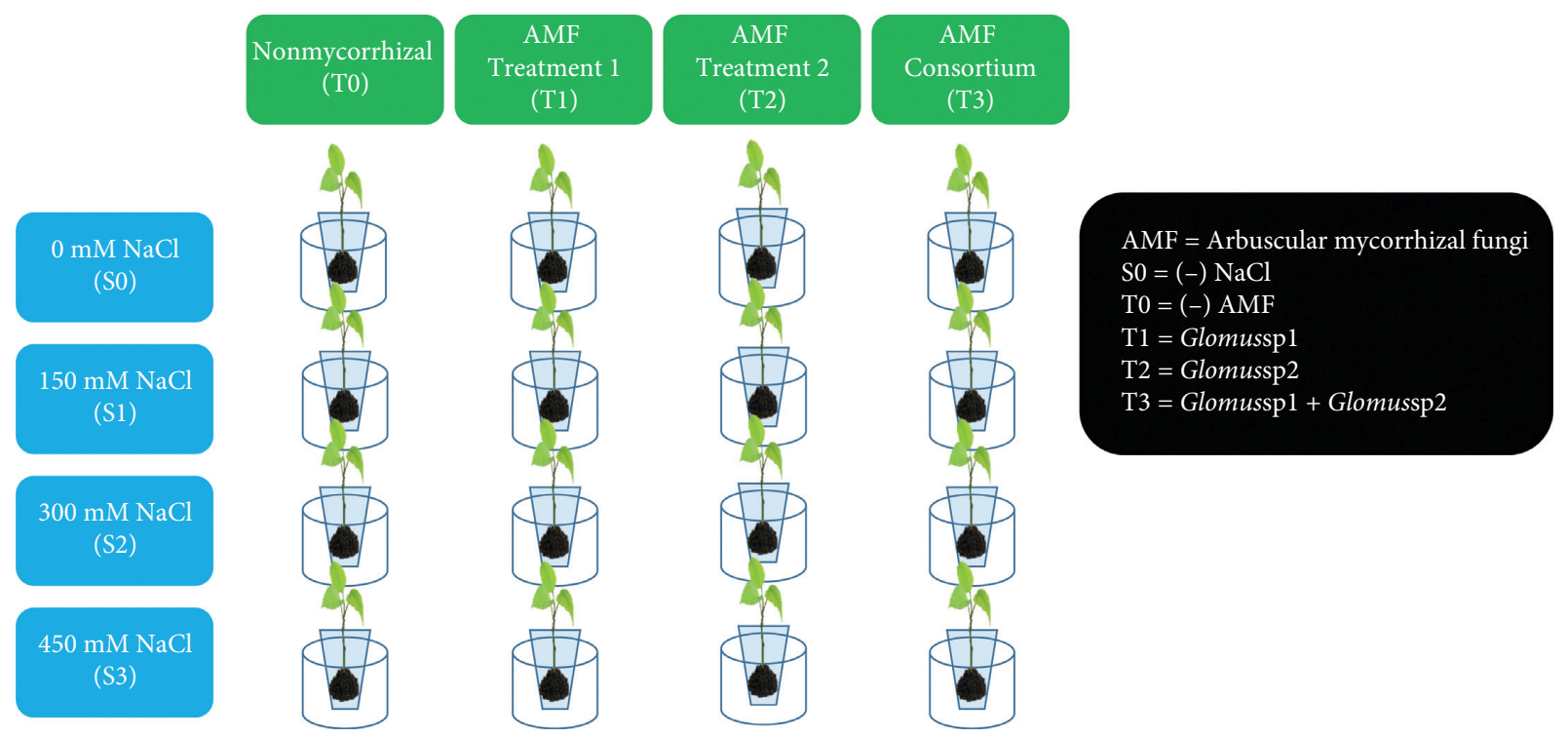

FIGURE 1: Experimental layout $(4 \times 4$ factorial $)$ for the greenhouse experiment, including salinity and AMF treatments. Each treatment had 5 replications.

at room temperature for $5 \mathrm{~min}$ and then read at $\mathrm{A}_{595}$. Estimation of leaf protein $(\mathrm{mg} / \mathrm{g})$ content was compared to the standard solution using bovine serum albumin (BSA).

2.7. Total Carbohydrate Content. Total carbohydrate containing polysaccharide and free sugars was estimated from the leaf sample solution as prepared previously using anthrone method [27]. The solution was acid-hydrolyzed using $\mathrm{HCN}$ and added with anthrone reagent. Samples were read at $\mathrm{A}_{630}$ and estimated for their carbohydrate content $(\mathrm{mg} / \mathrm{g})$ with the standard solution using glucose.

2.8. Proline Content. Leaf proline content was estimated from the leaf sample solution as prepared previously using the method described by Monneveux and Nemmar [28]. Samples were read at $\mathrm{A}_{520}$ and estimated for their proline content $(\mu \mathrm{mol} / \mathrm{g})$ with the standard solution using proline.

2.9. Data Analysis. The data were analyzed using a twofactor analysis of variance (ANOVA) obtained from salinity level and AMF treatment at the $\alpha$ level of $5 \%$, followed by a pairwise comparison with Tukey test using Minitab ver. 16.0. Graphical images were generated using GraphPad Prism ver. 8.0.2.

\section{Results}

3.1. Identification of Indigenous $A M F$. Two samples of indigenous AMF were sent for molecular identification. DNA sequencing result showed the sequence of amplified region (partial 18S (SSU), 5.8S (ITS), and partial 28S (LSU)) rDNA of two Glomus isolates, each with a size of $1,796 \mathrm{bp}$ for Glomus sp1 and 1,764bp for Glomus sp2. Based on the bioinformatic analysis and phylogenetic construction among members of Glomeromycota, it was revealed that
Glomus sp1 was identified as Glomus manihotis while Glomus sp2 was identified as Glomus etunicatum compared to the DNA sequence of Archaeospora trappei as an outgroup (Figure 2).

3.2. Effect of AMF Inoculation on Height and Biomass of L. leucocephala under Salt Stress. Results obtained after 1 month of growing L. leucocephala in greenhouse showed that the increasing $\mathrm{NaCl}$ concentration caused significant reduction to plant height of $L$. leucocephala seedlings from $21.5 \%(150 \mathrm{mM})$ to $44.6 \%(450 \mathrm{mM})$ compared to controls at $0 \mathrm{mM}$ (Figure 3 ). The biomass of L. leucocephala also experienced significant reduction from $20.96 \%(150 \mathrm{mM})$ to $61.35 \%(450 \mathrm{mM})$ compared to controls at $0 \mathrm{mM}$ (Figure 4 ). In the presence of AMF, the height and biomass of L. leucocephala seedlings were higher and significant compared to controls at all levels of salinity stress. The application of AMF consortium (G. manihotis + G. etunicatum) was observed to significantly alleviate the salt stress better than the application of single AMF species even matching the biomass in control plants at $150 \mathrm{mM}$ and $300 \mathrm{mM}$ treatments. In addition, the AMF consortium also promoted the best growth performance (height, biomass) of L. leucocephala seedlings in this study.

3.3. Effect of AMF Inoculation on the Total Protein, Carbohydrate, and Proline Contents of L. leucocephala Leaves under Salt Stress. The total protein, total carbohydrate, and total and proline contents in L. leucocephala fresh leaves were quantified after 1 month of salt stress and the results showed a significant increase in AMF-inoculated plants compared to control plants at all concentrations (Figures 5 and 6). The interaction between salinity and AMF treatment was not significant for total protein and proline content indicating that the salinity did not affect the AMF performance in 


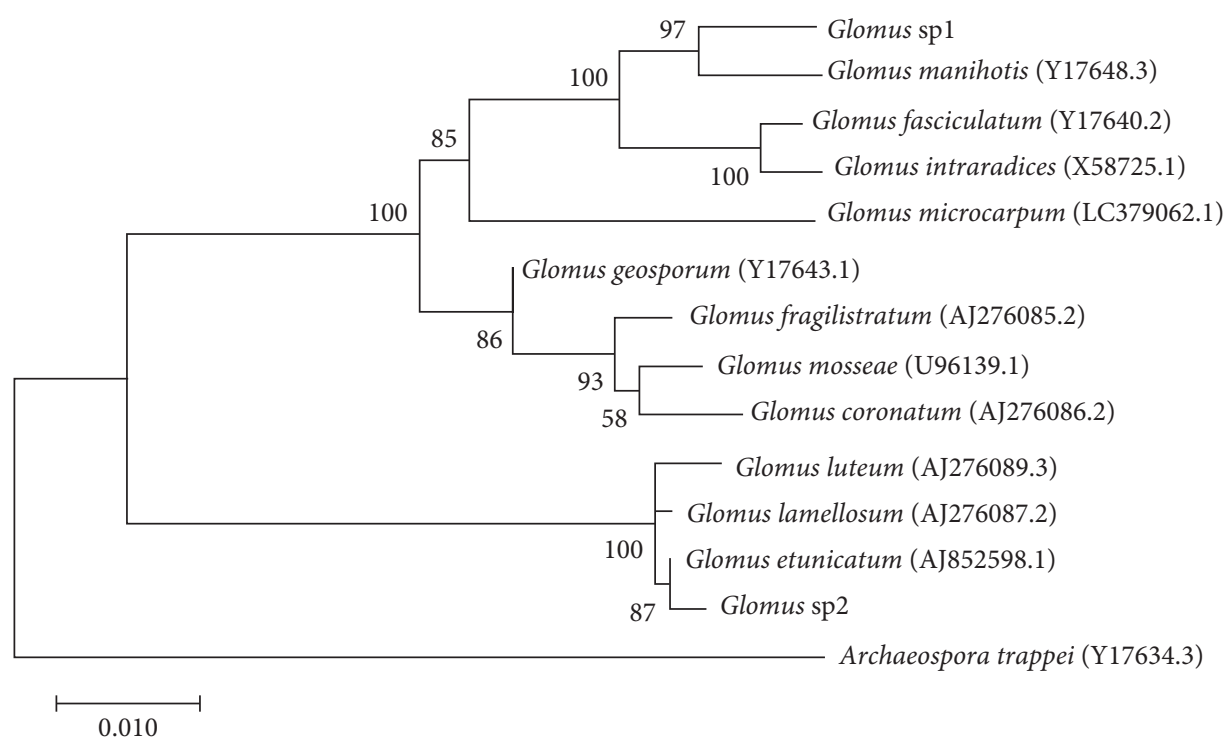

FIgURE 2: Phylogenetic tree of partial 18S (SSU), 5.8S (ITS), and partial 28S (LSU) rDNA sequences of 14 Glomeromycota representatives. Neighbor-joining (NJ) analysis including Archaeospora trappei as outgroup. Bootstrap values are given for each branch (BV $>50)$. Scale bar indicates the number of substitutions per site.

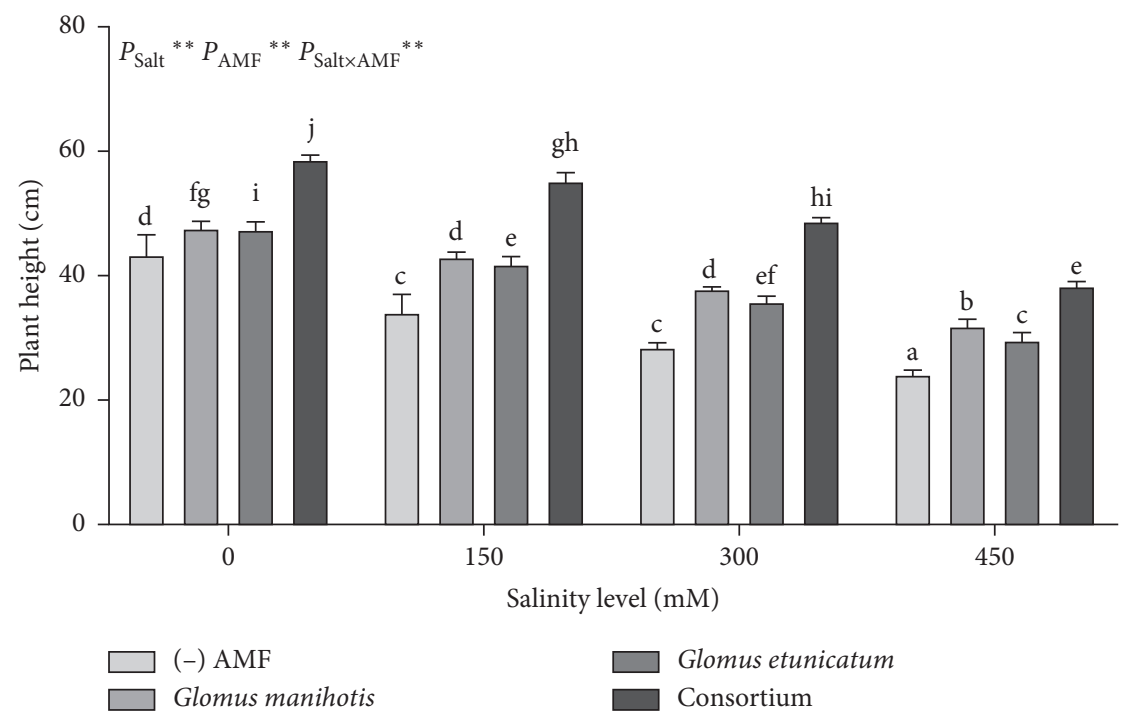

Figure 3: Effects of AMF inoculation on the height growth of L. leucocephala seedlings at different NaCl stress. AMF: arbuscular mycorrhizal fungi. ${ }^{*}$ : significant at $0.01 \leq P \leq 0.05$; $^{* *}$ : significant at $P \leq 0.01$. Bars that do not share a letter are significantly different at $P \leq 0.05$.

elevating or lowering the total protein and proline contents in L. leucocephala. Meanwhile, the total carbohydrate content in L. leucocephala leaves was significant in both treatment and its interactions between salinity and AMF treatment (Figure 7). The total protein and carbohydrate contents in control plants were observed for its maximum value at $150 \mathrm{mM} \mathrm{NaCl}$, although insignificant for total carbohydrate parameter. The highest proline content in control plants was observed at $300 \mathrm{mM}$ and insignificant among the group. The inoculation of AMF consortium increased the total protein, total carbohydrate, and proline content of L. leucocephala seedlings which almost was matched by the single inoculation of G. manihotis. Based on these results, it was revealed that the inoculation of
G. etunicatum did not play an important role in the accumulation of the proteins and sugars in L. leucocephala leaves compared to control plants.

3.4. Effect of Salt Stress on the Root Colonization of L. leucocephala. Root colonization of L. leucocephala by AMF isolates was observed microscopically after 1 month of salt stress. In control plants, no colonization was observed by other indigenous AMF due to the application of sterilized zeolites as growth medium. The microscopic images showed that each AMF treatment was successful as indicated by the presence of hyphal structures in all samples with some vesicles and few arbuscules (Figure 8). Soil salinity decreased 


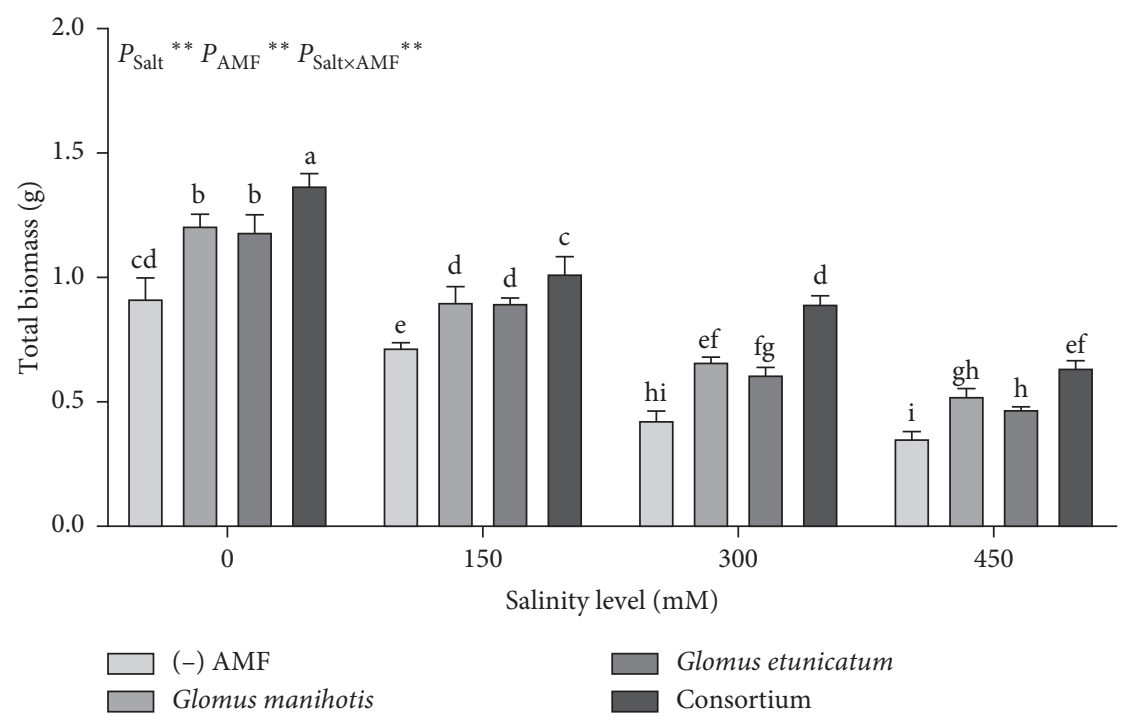

FIGURE 4: Effects of AMF inoculation on the biomass of $L$. leucocephala seedlings at different $\mathrm{NaCl}$ stress. AMF: arbuscular mycorrhizal fungi. *: significant at $0.01 \leq P \leq 0.05 ;^{* *}$ : significant at $P \leq 0.01$. Bars that do not share a letter are significantly different at $P \leq 0.05$.

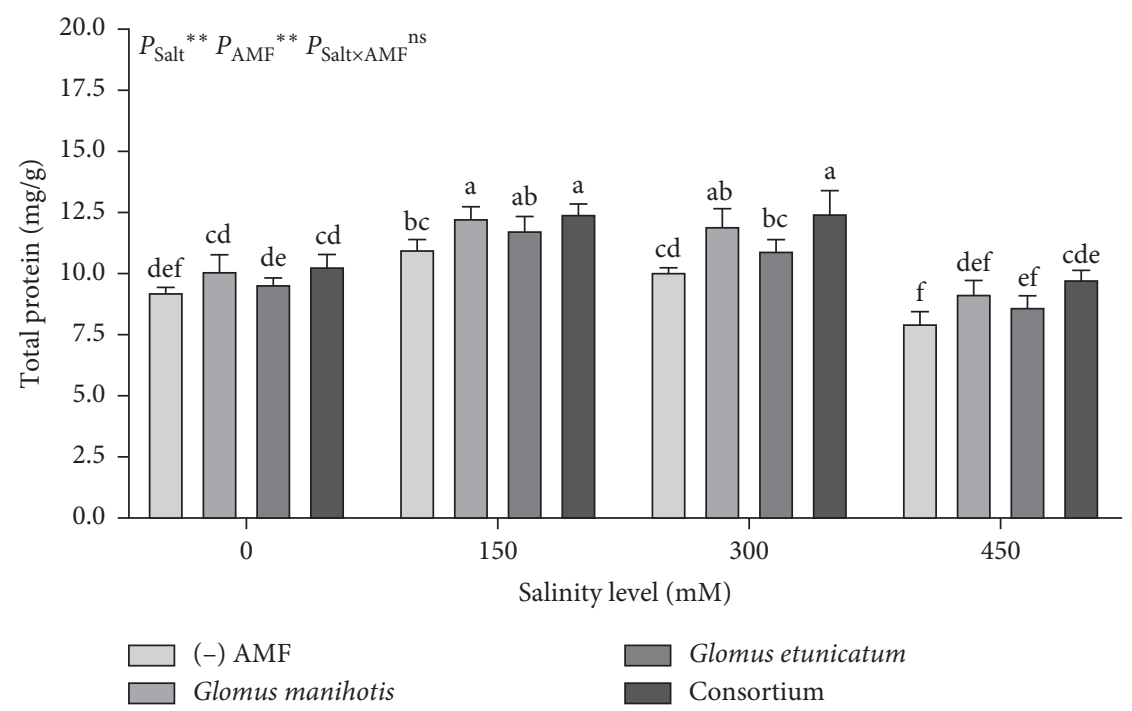

FIGURE 5: Effects of AMF inoculation on the total protein content of L. leucocephala leaves at different $\mathrm{NaCl}$ stress. AMF: arbuscular mycorrhizal fungi. * : significant at $0.01 \leq P \leq 0.05$; $^{* *}$ : significant at $P \leq 0.01$. Bars that do not share a letter are significantly different at $P \leq 0.05$.

the root colonization of L. leucocephala in all treatments. The AMF colonization decreased by $30 \%, 29 \%$, and $32 \%$ (in the G. manihotis, G. etunicatum, and AMF consortium, respectively) in the $450 \mathrm{mM}$ treatments compared to control plants $(0 \mathrm{mM} \mathrm{NaCl})$ (Figure 9). There was a significant difference between salinity and AMF treatments. The application of single AMF isolate, G. manihotis, almost matched the root colonization by the AMF consortium in the 150,300 , and $450 \mathrm{mM}$ treatments while the colonization by $G$. etunicatum was recorded the lowest in our study.

3.5. PCA Analysis. Multivariate analysis of all datasets was meant to depict the physiological response patterns of L. leucocephala to salt stress and AMF inoculation. Correlation among parameters was priorly analyzed using Pearson's correlation coefficient test (Table 1). The height of L. leucocephala was negatively correlated with the biomass which may indicate the limit of growing the seedlings in greenhouse. The carbohydrate content in L. leucocephala leaves was negatively correlated with the plant height and positively correlated with the biomass. The proline content was negatively correlated with the biomass indicating a stress response to the salt stress. Root colonization by AMF showed a high correlation with plant height, biomass, and carbohydrate content which indicated a growth promotion through better nutrient absorption facilitated by the fungi. In addition, the proline content in L. leucocephala leaves was less likely correlated with the root colonization by $\mathrm{AMF}$ which gave us a clue on other tolerance mechanisms under salt stress. All 


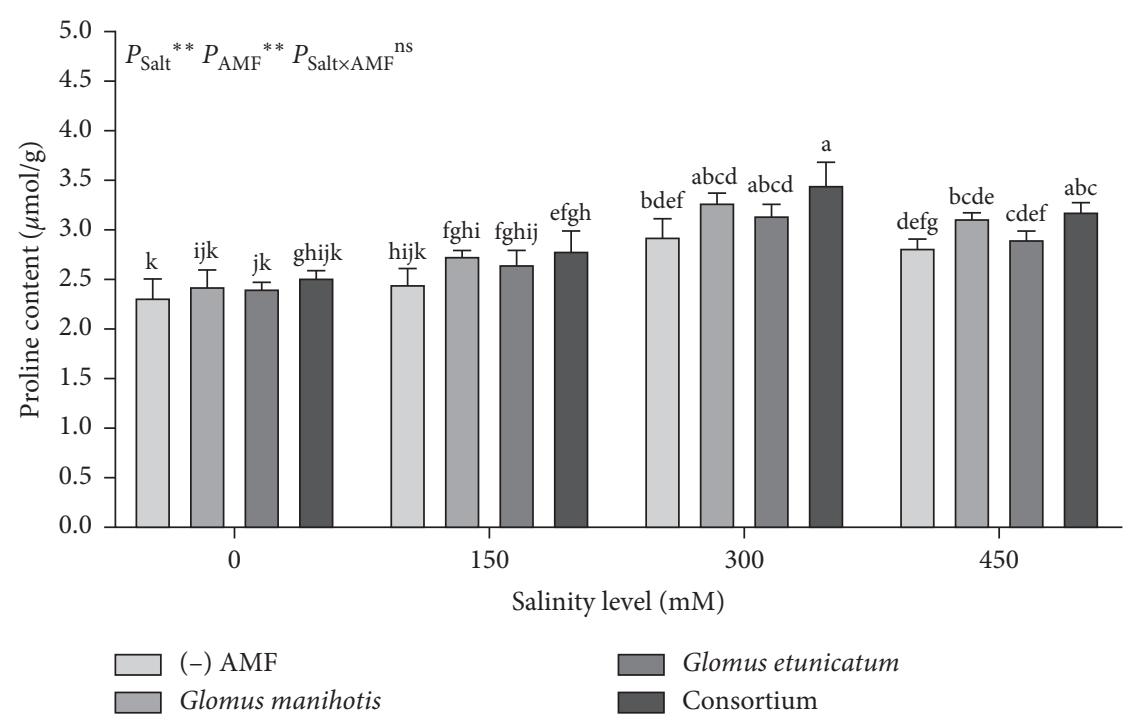

FiguRE 6: Effects of AMF inoculation on the proline content of $L$. leucocephala leaves at different NaCl stress. AMF: arbuscular mycorrhizal fungi. *: significant at $0.01 \leq P \leq 0.05{ }^{* *}$ : significant at $P \leq 0.01$. Bars that do not share a letter are significantly different at $P \leq 0.05$.

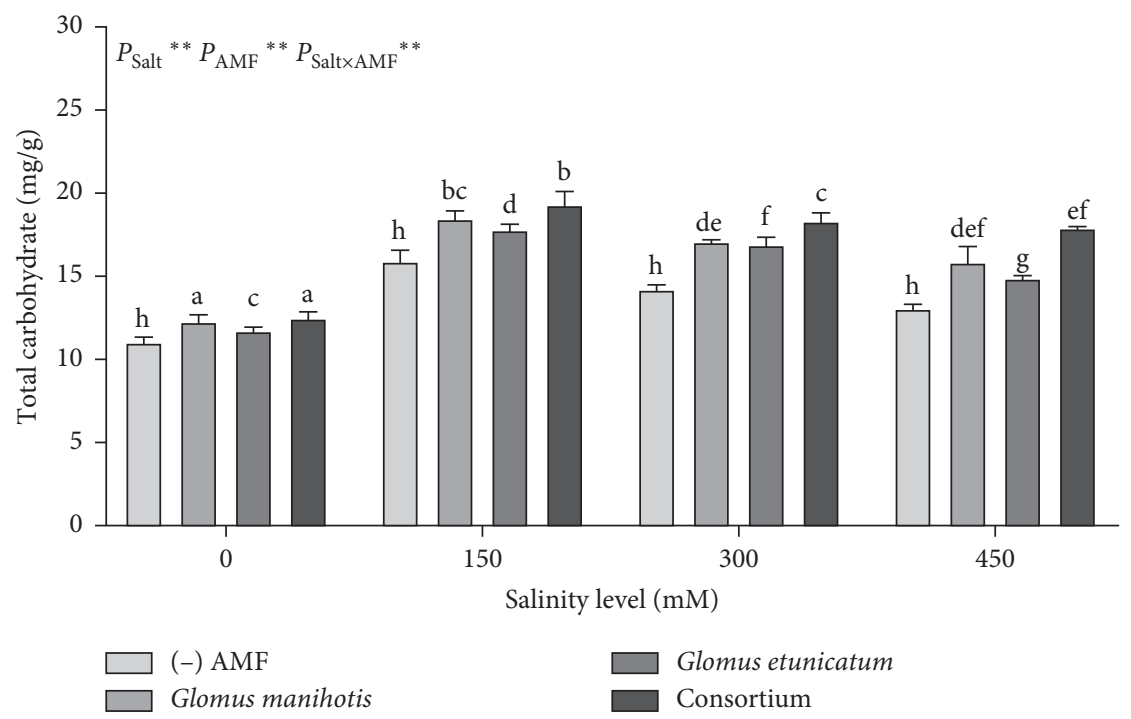

FIGURE 7: Effects of AMF inoculation on the total carbohydrate content of L. leucocephala leaves at different NaCl stress. AMF: arbuscular mycorrhizal fungi. *: significant at $0.01 \leq P \leq 0.05 ;^{* *}$ : significant at $P \leq 0.01$. Bars that do not share a letter are significantly different at $P \leq 0.05$.

parameters were standardized and reduced to the most representative dimensions. The distance between treatments in the score plot of PCA showed the similarity of tested parameters. The PCA components, PC1 and PC2, accounted for $57 \%$ and $25 \%$ of the variance, respectively, yet were categorized as optimum in depicting the correlation among parameters $\left(\mathrm{PC}_{1+2}>70 \%\right)$. Based on the plot, it can be seen that control plants and AMF-inoculated plants were separated in different quadrants showing distinct results of individual parameters (Figure 10). The growth response of L. leucocephala seedlings also tends to be grouped together under type of AMF treatment rather than at different salt levels. The application of either single AMF species or consortium could enhance the salt tolerance of L. leucocephala seedlings, especially at 150 and $300 \mathrm{mM} \mathrm{NaCl}$.

\section{Discussion}

Salinity stress is a global limiting factor that reduces the growth and viability of valuable plants cultivated in the agricultural fields [29]. Excessive salt ions in soil environment impose serious physiological stressors to the plants with the biological consequences like reduced photosynthesis capacity, cellular dehydration, and nutrient deficiencies [7, 18, 30]. The effect of AMF inoculation to L. leucocephala plants was studied through an experiment of different $\mathrm{NaCl}$ concentrations $(0,150,300$, and $450 \mathrm{mM})$ for 1 month under greenhouse. Inoculation of AMF into L. leucocephala seedlings has been reported previously and studied mostly under heavy metal toxicity experiments. AMF species such as Glomus aggregatum, Glomus 


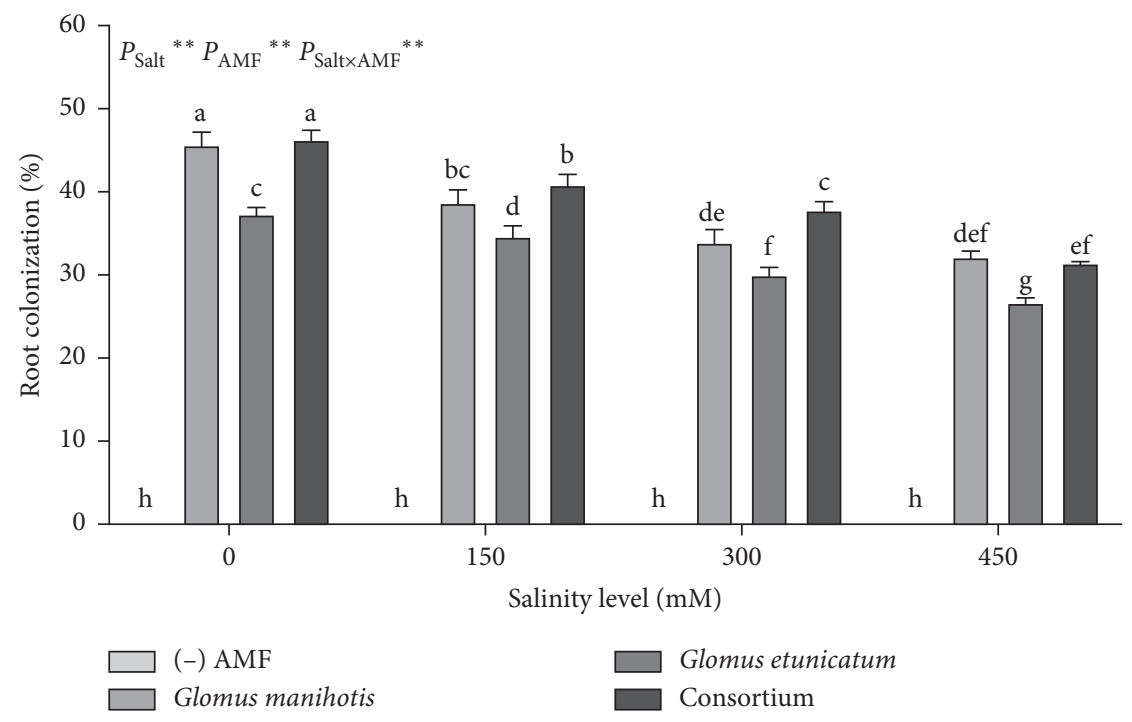

Figure 8: Examples of AMF structures as indicators of L. leucocephala colonization. A. Dissected root of L. leucocephala observed at 4x showing (a) external hyphae of AMF; B. Internal root tissue of L. leucocephala stained with trypan blue showing (a) hyphae and (b) vesicle observed at 400x; C. Root cell containing an (c) arbuscule observed at 1000x.

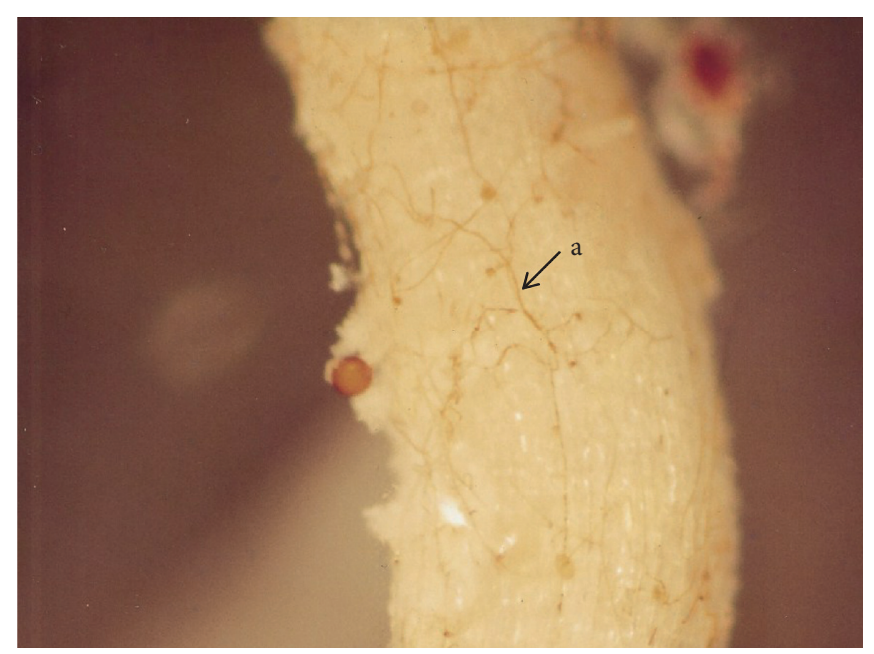

(a)

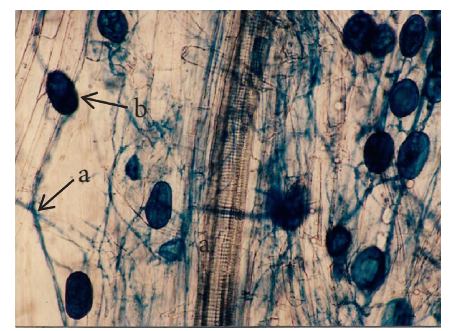

(b)

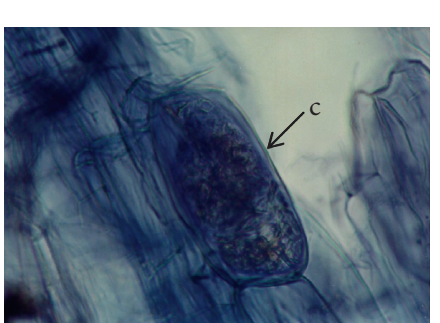

(c)

Figure 9: Effects of AMF inoculation on the root colonization of L. leucocephala seedlings at different NaCl stress. AMF: arbuscular mycorrhizal fungi. * : significant at $0.01 \leq P \leq 0.05 ;{ }^{* *}$ : significant at $P \leq 0.01$. Bars that do not share a letter are significantly different at $P \leq 0.05$.

etunicatum (syn. Claroideoglomus etunicatum), Acaulospora longula, and Acaulospora scrobiculata have been implemented successfully as bioameliorants in planta $[15,31,32]$. Our finding on G. manihotis (syn. Rhizophagus manihotis) as one of the indigenous AMF was considered unique since the species was known to be abundant in cassava $[33,34]$. In addition, there is still no recent record on the application of G. etunicatum, especially G. manihotis on L. leucocephala 
TABLE 1: Pearson's correlation matrix $(r)$ of all morphological and physiological parameters.

\begin{tabular}{lccccc}
\hline & Height & Biomass & Protein & Carbohydrate & Proline \\
\hline Height & & & & & \\
Biomass & -0.820 & & & & \\
Protein & -0.461 & 0.329 & & & \\
Carbohydrate & -0.672 & 0.595 & 0.431 & 0.157 & 0.157 \\
Proline & 0.135 & -0.492 & 0.277 & 0.815 & \\
Colonization & 0.762 & 0.595 & 0.431 & & \\
\hline
\end{tabular}

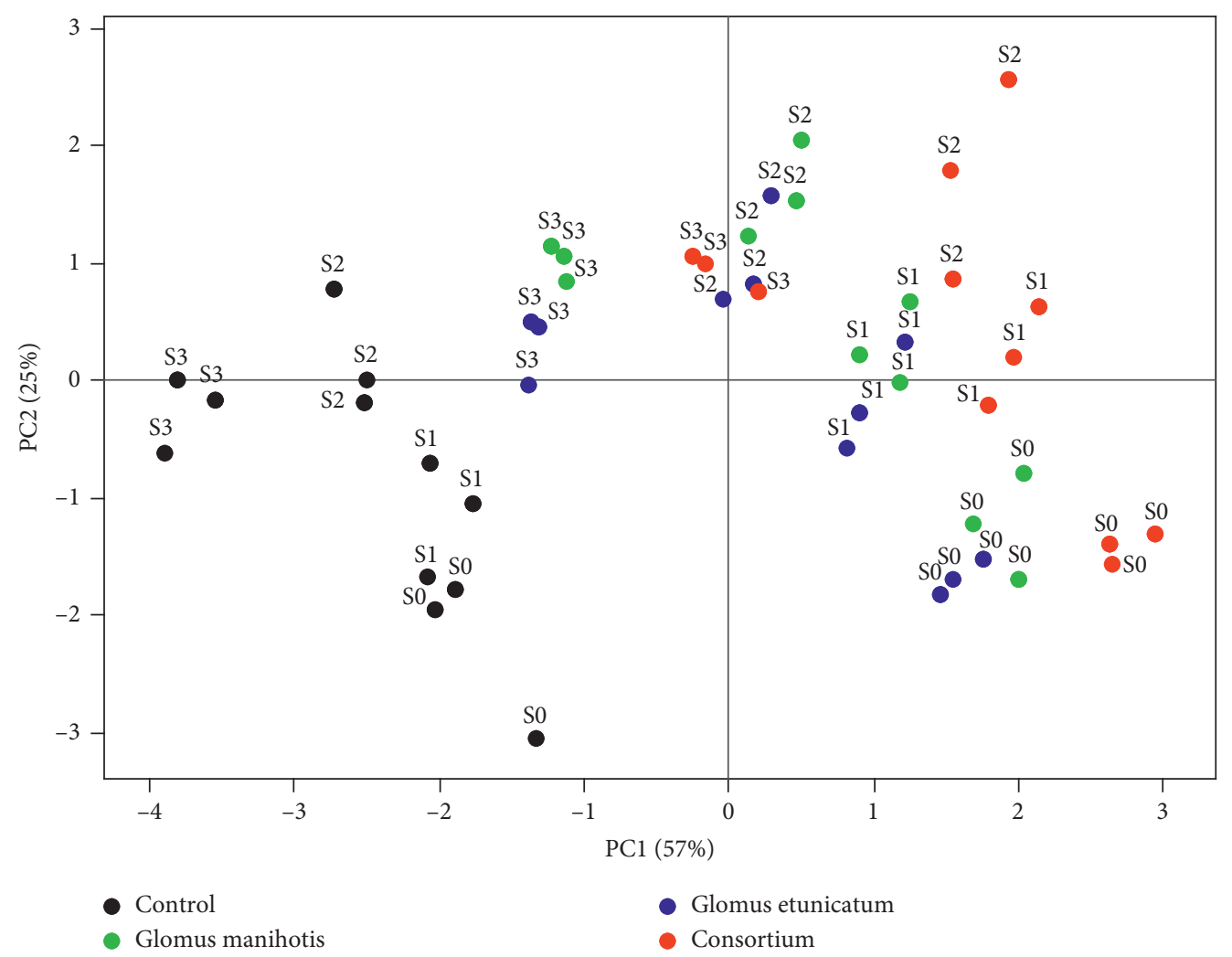

Figure 10: PCA plots of the two principal components of L. leucocephala, S0: control/0 mM NaCl, S1: $150 \mathrm{mM} \mathrm{NaCl,} \mathrm{S2:} 300 \mathrm{mM} \mathrm{NaCl}, \mathrm{S} 3$ : $450 \mathrm{mM} \mathrm{NaCl}$; PC1: principal component 1, PC2: principal component 2.

under salinity stress. Hence, our results may be beneficial for future investigation and possible formulation as a product. The AMF colonization rate in L. leucocephala roots was considered as stable under severe salt stress, although the highest percentage of colonization only reached $>30 \%$ for G. manihotis and AMF consortium in the $450 \mathrm{mM} \mathrm{NaCl}$ treatment. Salt stress may inhibit the mycelial growth and formation of vesicles in the mycelial network due to the toxicity of excessive sodium ions [35]. A significant decline in root colonization also indicated that the protective effect by preinoculation of AMF was less potent at higher salinity levels and diminished hereafter. In this study, the excessive salt ions reduced the root colonization capacity by AMF in the 150 and $300 \mathrm{mM} \mathrm{NaCl}$. The early response of L. leucocephala towards salt stress may be regulated in the form of delayed growth. Reduced cell growth of L. leucocephala manifested in the form of shorter plant and low biomass under salinity stress is normal but the application of AMF also proved to promote growth better than control plants $(0 \mathrm{mM} \mathrm{NaCl})$ in this study. Application of $\mathrm{AMF}$ is effective to support the vegetative growth of plants through improved root absorption especially phosphorus (P) under abiotic stress which helps to maintain the structural integrity or biomass of the plants [36]. Measurement of total soluble protein in $\mathrm{NaCl}$-affected L. leucocephala seedlings was meant to estimate the stability of dissolved membrane and pigment proteins. In this study, the interaction between salinity levels and AMF inoculation was not significant which means that there are other factors affecting the result. A study on a tall perennial cane species, Arundo donax, showed that the leaf protein content was lower in salt-stressed plants than control plants and the interaction was more likely by nutrition than AMF treatment. In addition, the chlorophyll content was not significant in the moderate salt stress as supplied by adequate $\mathrm{C}$ and $\mathrm{P}$ nutrition [37]. Another possible mechanism as revealed from the correlation test between root colonization and leaf protein content is that AMF may also stabilize the 
$\mathrm{Na}^{+}$translocation from the root system to the shoot system by maintaining internal $\mathrm{Na}+$ concentration in the mycelial network, thus preventing its accumulation and translocation into the photosynthetic tissues [38, 39]. Salinity may also induce the accumulation of glomalin, a typical heat shock protein produced by AMF in the soil environment [40]. However, the distribution of this protein was more likely to improve the soil integrity to maximize mineral and nutrient absorption for the host. It would be interesting for further study to evaluate these parameters in salt-stressed L. leucocephala. Tissue dehydration under salt stress may be prevented by the accumulation of osmolytes such as proline, sugars, organic acids, amino acids, and trehalose [41]. These molecules serve as osmoprotectants to stabilize protein and membrane integrity and scavenging of outgoing ROS incidence [42]. Here, the leaf proline content of salt-stressed L. leucocephala was quantified and showed that there was no significant interaction between salinity levels and AMF treatments. The reports on the accumulation of proline have been inconsistent between mycorrhizal and nonmycorrhizal plants [18]. However, it is generally accepted that under salt stress the accumulation of proline as a stress marker by plants is stable due to the presence of AMF involving other possible mitigation mechanisms [43]. Accumulation of carbohydrates or soluble sugars by plants is also considered as another salt-induced mechanism in adjusting the osmotic balance and as carbon storage [44]. Here, the sugar content in L. leucocephala leaves was considerably similar in control plants; however, there was a significant interaction between salinity levels and AMF treatments with the highest sugar content in the $150 \mathrm{mM} \mathrm{NaCl}$ compared to control plants and then decreasing hereafter. The relationship between root colonization and carbohydrate content was strongly correlated, which indicated that there was a significant contribution by AMF in the accumulation of soluble sugars in L. leucocephala. By considering the possible supportive feature by AMF in enhancing a nutrient absorption through root colonization, the higher quantity of soluble sugars under salt stress may be a result of an uninterrupted photosynthesis and rapid production of sucrose as carbon storage for further substrate decomposition and utilization for energy balance [45]. Consistent with the previous reports, the application of single AMF and its consortium could mitigate the output of salt stress and improve salt tolerance of L. leucocephala seedlings, although the parameters are finite and still need further investigation.

\section{Conclusions}

Salt stress induced several adjustments by L. leucocephala in terms of structural and physiological adjustments. Salt stress also reduced the root colonization of both AMF species, $G$. manihotis and G. etunicatum, in the 150, 300, and $450 \mathrm{mM} \mathrm{NaCl}$ treatments. However, the inoculation of AMF showed a significant relationship with the plant's ability to thrive in stressful conditions as being revealed from a steady height growth, biomass production, and total carbohydrate content. The application of AMF, especially the consortium, produced the highest result in enhancing a nutrient uptake, as indicated by a strong relationship between the root colonization and height, biomass, and carbohydrate content and multivariate analysis through PCA projection. Based on these results, the tolerance of $L$. leucocephala was improved to some degree, while also opening up the possibilities to further study in acquiring a deeper understanding of other possible mechanisms facilitated through an AMF symbiosis with the plants.

\section{Data Availability}

The data are available upon request provided by the corresponding author's laboratory record at the Department of Forestry, Faculty of Forestry, Universitas Sumatera Utara, Indonesia.

\section{Conflicts of Interest}

The authors declare that there are no conflicts of interest regarding the publication of this work.

\section{Acknowledgments}

The authors would like to express their highest gratitude to the head of laboratory and fellow researchers in the Laboratory of Forest Biotechnology, Research Center for Bioresources and Biotechnology (PPHSB), IPB University, Bogor, for facilitating the instrumentation and the laboratory facilities.

\section{References}

[1] C. L. Garcia, S. Dattamudi, S. Chanda, and K. Jayachandran, "Effect of salinity stress and microbial inoculations on glomalin production and plant growth parameters of snap bean (Phaseolus vulgaris)," Agronomy, vol. 9, no. 545, pp. 1-21, 2019.

[2] R. Porcel, R. Aroca, R. Azcón, and J. M. Ruiz-Lozano, "Regulation of cation transporter genes by the arbuscular mycorrhizal symbiosis in rice plants subjected to salinity suggests improved salt tolerance due to reduced $\mathrm{Na}+$ root-toshoot distribution," Mycorrhiza, vol. 26, no. 7, pp. 673-684, 2016.

[3] H. Marschner, Mineral Nutrition of Higher Plants, Academic Press, London, UK, 2 edition, 1995.

[4] P. H. Putri, G. W. Anggoro Susanto, and A. Taufiq, "Evaluasi ketahanan sumber daya genetik kedelai terhadap cekaman salinitas," Jurnal Penelitian Pertanian Tanaman Pangan, vol. 1, no. 3, pp. 233-242, 2017.

[5] Z. Li, N. Wu, S. Meng, F. Wu, and T. Liu, "Arbuscular mycorrhizal fungi (AMF) enhance the tolerance of Euonymus maackii Rupr. at a moderate level of salinity," PLoS One, vol. 15, no. 4, Article ID e0231497, 2020.

[6] D. Wulandari, Saridi, W. Cheng, and K. Tawaraya, "Arbuscular mycorrhizal colonization enhanced early growth of Mallotus paniculatus and Albizia saman under nursery conditions in East Kalimantan, Indonesia," International Journal of Forestry Research, vol. 2014, Article ID 898494, 8 pages, 2014.

[7] N. Begum, C. Qin, M. A. Ahanger et al., "Role of arbuscular mycorrhizal fungi in plant growth regulation: implications in 
abiotic stress tolerance," Frontiers in Plant Science, vol. 10, p. 1068, 2019.

[8] E. González-García, O. Cáceres, H. Santana, and H. Santata, "Nutritive value of edible forage from two Leucaena leucocephala cultivars with different growth habit and morphology," Agroforestry Systems, vol. 77, no. 2, pp. 131-141, 2009.

[9] A. R. Sharma and U. K. Behera, "Green leaf manuring with prunings of Leucaena leucocephala for nitrogen economy and improved productivity of maize (Zea mays)-wheat (Triticum aestivum) cropping system," Nutrient Cycling in Agroecosystems, vol. 86, no. 1, pp. 39-52, 2010.

[10] V. C. Pandey and A. Kumar, "Leucaena leucocephala: an underutilized plant for pulp and paper production," Genetic Resources and Crop Evolution, vol. 60, no. 3, pp. 1165-1171, 2013.

[11] R. Hendrati and N. Hidayati, "Nine Indonesian populations of Leucaena leucochepala (lam.) de wit. for wood-energy breeding versus var. Tarramba," Jurnal Perbenihan Tanaman Hutan, vol. 6, no. 1, pp. 15-30, 2018.

[12] R. L. Hendrati and S. H. Nurrohmah, "Genetic improvement of Leucaena leucocephala for wood energy," Tropical Grasslands-Forrajes Tropicales, vol. 7, no. 2, pp. 210-213, 2019.

[13] V. L. Goel and H. M. Behl, "Selection of Leucaena species for afforestation and amelioration of sodic soils," Land Degradation \& Development, vol. 13, no. 5, pp. 387-393, 2002.

[14] S. H. Gaida, B. Wasis, and S. W. Budi, "Application of arbuscular mycorrhizal fungi and soil ameliorant on the growth of Leucaena leucocephala in limestone post-mining soil media," Jurnal Manajemen Hutan Tropika, vol. 26, no. 3, pp. 282-290, 2020.

[15] K. G. V. Garcia, P. F. Mendes Filho, J. I. Pinheiro et al., "Attenuation of manganese-induced toxicity in Leucaena leucocephala colonized by arbuscular mycorrhizae," Water, Air, \& Soil Pollution, vol. 231, no. 1, p. 22, 2020.

[16] J. Schneider, J. Bundschuh, W. d. M. Rangel, and L. R. G. Guilherme, "Potential of different AM fungi (native from As-contaminated and uncontaminated soils) for supporting Leucaena leucocephala growth in As-contaminated soil," Environmental Pollution, vol. 224, pp. 125-135, 2017.

[17] R. M. Augé, H. D. Toler, and A. M. Saxton, "Arbuscular mycorrhizal symbiosis and osmotic adjustment in response to $\mathrm{NaCl}$ stress: a meta-analysis," Frontiers in Plant Science, vol. 5, p. 562, 2014.

[18] H. Evelin, T. S. Devi, S. Gupta, and R. Kapoor, "Mitigation of salinity stress in plants by arbuscular mycorrhizal symbiosis: current understanding and new challenges," Frontiers in Plant Science, vol. 10, p. 470, 2019.

[19] M. A. Selosse, C. Strullu-Derrien, F. M. Martin, S. Kamoun, and P. Kenrick, "Plants, fungi and oomycetes: a 400-million year affair that shapes the biosphere," New Phytologist, vol. 206, no. 2, pp. 501-506, 2015.

[20] R. Porcel, S. Redondo-Gómez, E. Mateos-Naranjo, R. Aroca, R. Garcia, and J. M. Ruiz-Lozano, "Arbuscular mycorrhizal symbiosis ameliorates the optimum quantum yield of photosystem II and reduces non-photochemical quenching in rice plants subjected to salt stress," Journal of Plant Physiology, vol. 185, pp. 75-83, 2015.

[21] R. Hajiboland, F. Dashtebani, and N. Aliasgharzad, "Physiological responses of halophytic C4 grass Aeluropus littoralis to salinity and arbuscular mycorrhizal fungi colonization," Photosynthetica, vol. 53, no. 4, pp. 572-584, 2015.

[22] E. Ashrafi, M. Zahedi, and J. Razmjoo, "Co-inoculations of arbuscular mycorrhizal fungi and rhizobia under salinity in alfalfa," Soil Science and Plant Nutrition, vol. 60, no. 5, pp. 619-629, 2014.
[23] M. Krüger, H. Stockinger, C. Krüger, and A. Schüßler, "DNAbased species level detection of Glomeromycota: one PCR primer set for all arbuscular mycorrhizal fungi," New Phytologist, vol. 183, pp. 212-223, 2009.

[24] J. Phillips and D. Hayman, "Improved procedures for clearing roots and staining parasitic and vesicular-arbuscular mycorrhizal fungi for rapid assessment of infection," Transactions of the British Mycological Society, vol. 55, pp. 157-160, 1970.

[25] M. Giovannetti and B. Mosse, "An evaluation of techniques for measuring vesicular arbuscular mycorrhizal infection in roots," New Phytologist, vol. 84, no. 3, pp. 489-500, 1980.

[26] M. M. Bradford, "A rapid and sensitive method for the quantitation of microgram quantities of protein utilizing the principle of protein-dye binding," Analytical Biochemistry, vol. 72, no. 1-2, pp. 248-254, 1976.

[27] J. E. Hedge and B. T. Hofreiter, Carbohydrate Chemistry, Academic Press, London, UK, 1962.

[28] K. Butcher, A. F. Wick, T. DeSutter, A. Chatterjee, and J. Harmon, "Soil salinity: a threat to global food security," Agronomy Journal, vol. 108, no. 6, pp. 2189-2200, 2016.

[29] C. Santander, R. Aroca, J. M. Ruiz-Lozano et al., "Arbuscular mycorrhiza effects on plant performance under osmotic stress," Mycorrhiza, vol. 27, no. 7, pp. 639-657, 2017.

[30] Y. Hu and U. Schmidhalter, "Drought and salinity: a comparison of their effects on mineral nutrition of plants," Journal of Plant Nutrition and Soil Science, vol. 168, no. 4, pp. 541-549, 2005.

[31] C. E. d. L. Lins, L. C. Maia, U. M. T. Cavalcante, and E. V. d. S. B. Sampaio, "Efeito de fungos micorrízicos arbusculares no crescimento de mudas de Leucaena leucocephala (Lam.) de Wit. em solos de caatinga sob impacto de mineração de cobre," Revista Árvore, vol. 31, no. 2, pp. 355-363, 2007.

[32] M. Habte and M. J. Antal Jr, "Reaction of mycorrhizal and NonmycorrhizalLeucaena leucocephalato charcoal amendment of mansand and soil," Communications in Soil Science and Plant Analysis, vol. 41, no. 5, pp. 540-552, 2010.

[33] C. J. Straker, A. J. Hilditch, and M. E. C. Rey, "Arbuscular mycorrhizal fungi associated with cassava (Manihot esculenta Crantz) in South Africa," South African Journal of Botany, vol. 76, no. 1, pp. 102-111, 2010.

[34] C. P. Peña-Venegas, T. W. Kuyper, J. Davison et al., "Distinct arbuscular mycorrhizal fungal communities associate with different manioc landraces and Amazonian soils," Mycorrhiza, vol. 29, no. 3, pp. 263-275, 2019.

[35] A. Hashem, A. A. Alqarawi, R. Al-Arjani, H. A. Aldehaish, D. Egamberdieva, and E. F. Abd_Allah, "Arbuscular mycorrhizal fungi regulate the oxidative system, hormones and ionic equilibrium to trigger salt stress tolerance in Cucumis sativus L," Saudi Journal of Biological Sciences, vol. 25, no. 6, pp. 1102-1114, 2018.

[36] T. R. Cavagnaro, F. A. Smith, S. M. Ayling, and S. E. Smith, "Growth and phosphorus nutrition of a Paris -type arbuscular mycorrhizal symbiosis," New Phytologist, vol. 157, no. 1, pp. 127-134, 2003.

[37] A. Romero-Munar, E. Baraza, J. Gulías, and C. Cabot, "Arbuscular mycorrhizal fungi confer salt tolerance in giant reed (Arundo donax L.) plants grown under low phosphorus by reducing leaf $\mathrm{Na}+$ concentration and improving phosphorus use efficiency," Frontiers in Plant Science, vol. 10, p. 843, 2019.

[38] F. Maathuis and A. Amtmann, "K+Nutrition and Na+Toxicity: the basis of cellular $\mathrm{K}+/ \mathrm{Na}+\mathrm{Ratios}$," Annals of Botany, vol. 84, no. 2, pp. 123-133, 1999. 
[39] H. Evelin, B. Giri, and R. Kapoor, "Contribution of glomus intraradices inoculation to nutrient acquisition and mitigation of ionic imbalance in $\mathrm{NaCl}$-stressed Trigonella foenumgraecum," Mycorrhiza, vol. 22, no. 3, pp. 203-217, 2012.

[40] E. C. Hammer and M. C. Rillig, "The influence of different stresses on glomalin levels in an arbuscular mycorrhizal fungus-salinity increases glomalin content," PLoS One, vol. 6, Article ID e28426, 2011.

[41] T. H. H. Chen and N. Murata, "Glycinebetaine protects plants against abiotic stress: mechanisms and biotechnological applications," Plant, Cell \& Environment, vol. 34, no. 1, pp. 1-20, 2011.

[42] G. Kaur and B. Asthir, "Proline: a key player in plant abiotic stress tolerance," Biologia Plantarum, vol. 59, no. 4, pp. 609-619, 2015.

[43] A. I. Sannazzaro, M. Echeverría, E. O. Albertó, O. A. Ruiz, and A. B. Menéndez, "Modulation of polyamine balance in Lotus glaber by salinity and arbuscular mycorrhiza," Plant Physiology and Biochemistry, vol. 45, no. 1, pp. 39-46, 2007.

[44] A. Parvaiz and S. Satyawati, "Salt stress and phyto-biochemical responses of plants-a review," Plant, Soil and Environment, vol. 54, no. No. 3, pp. 89-99, 2008.

[45] N. Garg and A. Bharti, "Salicylic acid improves arbuscular mycorrhizal symbiosis, and chickpea growth and yield by modulating carbohydrate metabolism under salt stress," Mycorrhiza, vol. 28, no. 8, pp. 727-746, 2018. 